\title{
The Implication of Affirmative Action Implementation on Women's Representation Enhancement at Legislative Institution of Bali Province
}

\author{
I Gusti Bagus Suryawan ${ }^{1}$, Ida Ayu Putu Widiati ${ }^{2}$, Indah Permatasari ${ }^{3}$ \\ \{suryawanmeraku@gmail.com ${ }^{1}$ \} \\ Faculty of Law Universitas Warmadewa Denpasar-Bali, Indonesia ${ }^{123}$
}

\begin{abstract}
Women's representation in the public sphere is an indispensable component in contributing to policy making. However, the subsequent problem to arise is that until now the representation of women, especially in the legislature, has still received a less serious attention. Affirmative policy related to women's representation in politics is reflected in Law Number 2 of 2011 concerning Amendments to Law Number 2 of 2008 on Political Parties and Law Number 7 of 2017 toward Elections. The rules regarding affirmative action do not necessarily affect significantly the amount of women's representation in the legislature, especially in the Province of Bali. The amount of women's representation in the DPRD (Regional People's Representative Council) of the Province of Bali in the 2014-2019 period only reached $9.09 \%$. The level increase is only $1.69 \%$ compared to the previous 2009-2014 period. Whereas in the DPD (Regional Representative Council) of Bali Province there has not been found any representation of women during the two periods, namely the period 2009-2014 and 2014-2019. The low rate of representation of women in the legislative institutions in Bali Province is influenced by several factors, i.e. internal factors and external factors.
\end{abstract}

Keywords: Land Tenure, Foreign Citizens.

\section{Introduction}

The Republic of Indonesia is a country that upholds dtemocracy. Democracy is a form of government that is structured and organized based on the principle of popular sovereignty, political equality, consultation or dialogue with the people (popular consultation), and based on majority rule [1]. Political parties have a status and a role that is very important in every democratic system [2]. The presence of political parties can be seen as one of the characteristics of a democratic government. This is because political parties are one form of organization as a vehicle for the exercise of the right to freedom of expression and freedom of assembly and association [3]. Based on Article 1 number 1 of Law Number 2 of 2011 concerning Amendments to Law Number 2 of 2008 concerning Political Parties, Political Parties are national organizations and are formed by a group of Indonesian citizens voluntarily on the basis of similarity of will and aspirations to fight for and defend the political interests of members, society, nation and state, and maintain the integrity of the Unitary State of the Republic of Indonesia based on Pancasila and the 1945 Constitution of the Republic of Indonesia. Political Parties also function as a means of articulating communication and aggregating the aspirations of the people to be processed, delivered and defended by representatives of political parties involved in the policy process [4]. 
Democracy mandates the equality of roles for men and women, especially in formal politics. Unfortunately, in a realiy there are still gaps in gender, especially in political participation and decision making. Like men, women's representation in the public sphere actually has a non-negotiable role, especially as a realization of the right to equality as citizens. Unfortunately, so far in Indonesia, the rate of representation of women in the public sphere, especially politics is still below the average compared to those of men. Therefore, to increase women's representation in the public sphere, especially in formal politics, an affirmative action is compiled and formed. Indonesia is one of the countries that applies affirmative action to increase the number of women in the realm of political decision making [4].

The involvement of women in political parties has been guaranteed by a law on Political Parties that once took effect in the reform era, namely Law No. 2 of 2008 and Law No. 2 of 2011, which basically regulates an affirmative action so that political parties involve female cadres in the management structure of political parties at all levels by $30 \%$. In fact, one of the conditions for establishing a political party to be registered is to include at least $30 \%$ of women as party founders. Law Number 7 of 2017 concerning Elections also pays attention to women's representation, where in the provisions of Article 241 and Article 243, it is stipulated that the quota for women's representation is as much as $30 \%$ as candidate members for People's Representative Council (DPR), Regional Representative Assembly (DPD), Provincial People's Representative Council (Provincial DPRD) and Regency/Manucipal DPRD.

Table 1. Womens' Representation at $D P R$ and $D P D$

\begin{tabular}{ccccc}
\hline \multirow{2}{*}{ Period } & \multicolumn{2}{c}{ DPR $(\mathbf{N}=\mathbf{5 6 0})$} & \multicolumn{2}{c}{ DPD $(\mathbf{N}=\mathbf{1 3 2})$} \\
\cline { 2 - 5 } & Women & Men & Women & Men \\
\hline $1999-2004$ & $46(9 \%)$ & $454(91 \%)$ & \multicolumn{2}{c}{$D P D$ was not formed } \\
\hline $2004-2009$ & $65(11,6 \%)$ & $435(88,4 \%)$ & $28(21,2 \%)$ & $104(78,8 \%)$ \\
\hline $2009-2014$ & $101(18 \%)$ & $459(82 \%)$ & $36(27,7 \%)$ & $96(72,3 \%)$ \\
\hline $2014-2019$ & $97(17,3 \%)$ & $463(82,7 \%)$ & $34(25,8 \%)$ & $98(74,2 \%)$
\end{tabular}

Source: Ministry of Women's Empowerment and Child Protection of the Republic of Indonesia [4].

Through data presented in Table 1, it can be seen that women's representation in Bali's legislative institutions during four consecutive periods is instensely inadequate. Thus, it is presumed that gaps in the form of gender discrimination in formal political institutions exist which ultimately results in the birth of policies that are unneutral. Based on these conditions, this study examines the regulation of affirmative action related to women's representation in the legislature in Bali Province, the affirmative action implications of increasing women's representation in the legislature in Bali Province, as well as factors that influence the inadequate rates representation of women in the legislature in Bali Province. 


\section{Method}

This study is an empirical legal research. The data used in this study are primary data and secondary data. Data collection techniques used are interview techniques. This study applies a non-probability/non-random sampling technique in collecting data. This technique is an opposite of probability sampling technique, which is that every human unit does not have the same opportunity to be selected as a sample [5]. The entire data collected, both in the form of primary data and secondary data, are processed and analyzed by structuring them systematically, classified, and linked between one data and the other data. The results of data analysis are presented qualitatively and systematically [5].

\section{Result and Discussion}

\subsection{Affirmative Action Arrangement Regarding Women's Representation in the Legislative Institution in Bali Province}

Indonesia as a country that upholds democracy certainly gives great attention to problems related to women's representation in politics. More importantly, Indonesia is one of the countries that applies affirmative action to increase the number of women in the realm of political decision making [4]. This affirmative action emerged to increase women's representation in politics. Increasing the representation of women in the legislative body, both in quantity and quality, is a necessity in order to create equality and justice between men and women to jointly participate in the process of public policy formulation. Not only Indonesia, other countries also implement affirmative action as an effort to increase women's representation in the legislature. One of the countries that implemented this affirmative action regarding women's representation was Korea.

The seriousness of the government in terms of making efforts to increase women's representation in the political field can be seen from the existence of legal rules governing women's representation in the political field. Again, affirmative action is a policy that appears as a manifestation of efforts made by the government to enhance the rate of representation of women in the political field. The creation of equality and justice between the rights of women and men in the political sphere of the state, both in quantity and in quantity is the goal of the establishment and formulation of provisions concerning affirmation policies, so that both women and men each have the same role and involvement in holding the interests of the nation and state, especially in the political world.

The role of the government in defending for the women's political rights experienced a complicated process, which began with the ratification of the Law of the Republic of Indonesia Number 68 of 1958 concerning the Approval of the Convention on the Political Rights of Women. This law emerged as a real form of the effort by the government to support the political rights of women. In the law, it is regulated regarding the right of women to vote in all elections with the equal conditions as men, without any discrimination. Women can also be elected in all electoral bodies, established by national law, with the equal conditions as for men, and without discrimination. In addition to this, in this Law, regarding the right of women to hold a public office and carry out all general duties is also regulated, namely those established by national law, with the equal conditions as for men, and without discrimination. Affirmative action also appears in several other laws and regulations in Indonesia, i.e. in Law 
Number 8 of 2012 concerning General Elections of Members of the House of Representative Council, Regional People's Representatives and Regional House of Representative Council; and in Law Number 2 of 2011 concerning Amendments for Law Number 2 of 2008 concerning Political Parties and in Law Number 7 of 2017 ragarding Elections.

Table 2. Affirmative Action Regarding Women's Representation in Legislation in Indonesia

Affirmative Action Regarding Women's Representation in Legislation in
Indonesia
'Law of the Republic of Indonesia Number 68 of 1958 concerning Approval of the
Convention on the Political Rights of Women'
'Law Number 12 of 2003 concerning General Elections of Members of the People's
Representative Council, and Regional People's Representative Council'
'Law Number 8 of 2012 concerning General Elections of Members of the People's
Representative Council, Regional Representative Council and Regional People
Representative Council'
'Law Number 2 of 2008 concerning Political Parties'
'Law Number 2 of 2011 concerning Amendments to Law Number 2 Year 2008
concerning Political Parties'

'Law Number 7 of 2017 concerning Elections.'

Source: Data processed by the authors based on the relevant laws and regulations

Affirmative action, especially those relating to women's representation in the political world, initially emerged through the ratification of the enactment of Law Number 12 of 2003 concerning Elections of the DPR, DPD and DPRD. This can be seen in the provisions of Article 65 paragraph (1) which stipulates that each political party participating in the election can submit candidates for DPR, Provincial DPRD and Regency/Manucipal DPRD for each Electoral District with regard to women's representation of at least $30 \%$. This law was later amended by Law Number 8 of 2012 concerning General Elections of the Members of the Peoples' Representative Council, Regional Representative Council and Regional People's Representative Council, which also concerns the women's representation by at least $30 \%$, as regulated in the provisions of Article 55.

Law Number 7 of 2017 concerning Elections emerged as a unifying law between Law No. 42 of 2008 concerning General Elections of the President and Vice President, Law Number 15 of 2011 concerning the Implementation of General Elections, and Law Number 8 In 2012 concerning the General Election of the Members of the People's Representative Council, the Regional Representative Council and the Regional People's Representative Council. The unification of these Acts is carried out as a form of simplification to become one law as the legal basis for simultaneous elections. This law also regulates the representation of women, both in political parties and as candidates for the $D P R, D P D$, Provincial $D P R D$ and Regency/manucipal $D P R D$. The provisions of this affirmative action are stipulated in Article 170, which determine that Political Parties can become participants of the election after fulfilling the requirements: shall include at least 30\% (thirty percent) of women's representation in the management of central political parties. In addition to the above article, the provisions regarding affirmative action are also regulated in Article 245, which stipulate the list of candidates for $D P R, D P D$, Provincial $D P R D$ and Regency/manucipal $D P R D$, which contain women's representation of at least $30 \%$ (thirty percent). 


\subsection{Implications of Affirmative Action on Increasing Women's Representation in the Legislative Institution in Bali Province}

The involvement of women in political parties has been guaranteed by the Law on general elections namely Law Number 7 of 2017, which basically regulates affirmative action so that political parties involve female cadres in the management structure of political parties at all levels by $30 \%$ and regulate at least $30 \%$ representation of women as candidates for the $D P R, D P D$ and $D P R D$. Even one of the conditions for the establishment of a political party in order to be registered is to include at least $30 \%$ of women as party founders. Judging from the legal substance, actually there are concrete legal rules stipulating the representation of women in the political sector, especially in the legislature. However, there is an emerging problem, that is, whether this policy has implications for increasing the rate of representation of women in the legislative body or not. The existence of affirmative action reflected in legislation relating to elections is expected to be a solution to increase the rate of women's representation in the political sector and provide opportunities for women to take part in politics.

The Regional People's Representative Council of the Province of Bali and the Regional Representative Council of the Province of Bali have an important role in formulating public policy. As with the People Representative Council and the Regional Representative Council, there are rules governing women's representation in the DPRD, namely the existence of rules involving women's representation in the Provincial Regional People's Representative Council candidates, namely $30 \%$ (thirty percent).

Table 3. Representation of Women at Bali Provincial $D P R D$ and $D P D$

\begin{tabular}{lllll}
\hline \multirow{2}{*}{ Period } & \multicolumn{2}{l}{ Bali Provincial } & DPRD & \multicolumn{2}{l}{ Bali Provincial DPD } \\
\cline { 2 - 5 } & Women & Men & Women & Men \\
\hline $2009-2014$ & $4(7,4 \%)$ & $50(92,59 \%)$ & $0(0 \%)$ & $4(100 \%)$ \\
\hline $2014-2019$ & $5(9,09 \%)$ & $50(90,9 \%)$ & $0(0 \%)$ & $4(100 \%)$
\end{tabular}

Source: Data obtained from the Secretariat of Bali Provincial DPRD and Bali Provincial DPD

Table 3 shows that there is an increase in the number of women's representation in the DPRD Bali Province, which is $1.69 \%$. However, this number does not show a significant increase. When compared with male representation, the number of female representation is still lower. The number of female representation in the DPRD in the Province of Bali in the 2014-2019 period only reached 9.09\%, not even reaching $10 \%$ of the total men's representation. Likewise the representation in the DPD of the Province of Bali, if carefully observed in Table 3, the absence of women's representation in the institutions of the two institutions is seen, respectively from the period 2009 to 2019. Thus, in the two institutions, women's representation is still far inadequate.

The existence of the affirmative action is expected to increase the representation of women in the legislative body, both in quantity and quality, which is a necessity in order to create equality and justice between men and women to both participate in the process of public policy formulation. Although women's representation has been regulated in the legislation, this affirmative action does not necessarily affect significantly the increase in the number of women's representation in the legislative institutions in Bali Province.

\subsection{Leading Factors to the Inadequate of Women's Representaion in Legislative Institution in Bali Province}


The existence of women in the legislature is something inevitable. If it is reviewed in terms of legal substance, the concrete legal rules governing women's representation in the political sector do exist, especially in the legislature. However, in practice, the application of the law does not have significant implications for the increase in the number of women's representation in the legislature in Bali Province. One of the institutions concerning with the issue of women's representation is the Indonesian Political Women Caucus (KPPI) of the Province of Bali. The Chairperson of the Indonesian Political Women Caucus (KPPI) of Bali Province, Dewa Ayu Sri Wigunawati, stated that affirmative action related to efforts to increase women's representation is an important thing to carry out, which later women in the legislature are able to make policies that voice the women's interests, both in the fields of education, health, protection of children, or in other fields. She added that the low representation of women in the legislature was influenced by the internal factors of the women themselves.

Increasing the women's representation in politics is not an easy thing. Although the government has established affirmative action both in the Election Law and in the Political Party Law, the policy has not been able to optimally increase the rate of representation of women in the legislature. Like information obtained from the explanation of the Chairperson of the KPPI, the government must be more serious if it really deserves to increase the rate of women's representation involvement in the political sector. The government should facilitate and help prospective women cadres and party cadres, in terms of providing assistance in the form of props, as well as counseling on political education. Thus, the rate of quality and quantity of women in the political field can be increased.

Inadequate representation of women in the legislature is of course caused by certain factors. The factors that influence this are internal factor and external factor. Internal factors that lead to the inadequate representation of women in the legislature are the low motive and interest of women in the political field. In addition to this, influential external factors are resulted from the hereditary culture and patriarchal mindset which consider the politics as the realm and scope for men's lives, and aside from these factors there are still many women who are less interested in politics as due to the doctrine and the perception that politics is outrageous [6].

Given that increasing the rate of women's involvement or representation in the political sector is very complicated, political education can be used as a means to prepare the women for the sector. Women should get political education from the party where they take shelter to increase intelligence to advance women to be able to appear balanced with the political elites of men who have dominated in a sustainable manner [6]. Based on Article 1 number 4 of Law Number 2 Year 2011 concerning Amendments to Law Number 2 of 2008, what is meant by Political Education is the learning and understanding processes of the rights, obligations and responsibilities of every citizen in the life of the nation and state. Political education is expected to be able to enhance quality and improve the paradigm that emerges, in that, women also have the rights and obligations to be elected as people's representatives and voice their aspirations. Political parties also have a central role in recruiting the women's cadres as well as providing political education so that they can improve quality which has an impact on increasing their representation in the legislature, especially in the Province of Bali. 


\section{Conclusion}

Affirmative action relating to women's representation in the political field is reflected in Law Number 7 of 2017 concerning Elections, especially in the provisions of Article 170 concerning including at least $30 \%$ (thirty percent) of women's representation in the management of political parties, and Article 245 which regulates the list of candidates for People's Representative Council, Regional Representative Council, Provincial Regional People's Representative Council and Regency/Manucipal Regional People's Representative Council contains a representation of women at least $30 \%$ (thirty percent). The existence of the rules regarding affirmative action does not necessarily affect significantly the amount of women's representation in the legislature, especially in the Province of Bali. The number of women's representation in the Regional People's Representative Council in the Province of Bali in the 2014-2019 period only reached $9.09 \%$ and it was lower than the representation of men at $90.9 \%$. The increase in the number of women's representation in the Regional People's Representative Council Bali Province institutions was 1.69\% compared to the previous period 2009-2014. Whereas, in the Regional Representative Council of Bali Province, women's representation has not been found for two consecutive periods, namely the period 2009-2014 and 2014-2019. Inadequate representation of women in legislative institutions, especially in the Province of Bali, is influenced by internal factors and external factors.

\section{Acknowledgment}

The authors would like to thank all the parties who have helped and contributed in the writing of this research. Hopefully, this paper can be useful theoretically and practically as the addition and development of knowledge, especially in the field of legal science.

\section{References}

[1] Toha, M.: Birokrasi Politik. Prenada Media Group, Jakarta (2014)

[2] Asshiddiqie, J.: Pengantar Ilmu Hukum Tata Negara. PT. Raja Grafindo, Jakarta (2016)

[3] Asshiddiqie, Jimly., dkk.: Konstitusi dan Ketatanegaraan Indonesia Kontemporer. PT. Biography Institute, Jakarta (2007)

[4] Kementerian Pemberdayaan Perempuan dan Perlindungan Anak Republik Indonesia, Panduan Fasilitator Modul Peningkatan Kapasitas Politik Kebangsaan Perspektif Gender. Kemenpppa RI, Jakarta (2013)

[5] Amiruddin \& Asikin, Z.: Pengantar Metode Penelitian Hukum. PT. Raja Grafindo, Jakarta (2008)

[6] Rasyidin \& Aruni, F.: Gender dan Politik, Keterwakilan Wanita Dalam Politik. Unimal Press, Aceh Utara (2016) 